\title{
Hydromorphological analysis and water balance modelling of ombro- and mesotrophic peatlands
}

\author{
F. Edom ${ }^{1}$, A. Münch ${ }^{2}$, I. Dittrich ${ }^{2}$, K. Keßler ${ }^{2}$, and R. Peters ${ }^{3}$ \\ ${ }^{1}$ Hydrotelm, 01139 Dresden, Germany \\ ${ }^{2}$ Dr. Dittrich and Partner Hydro-Consult GmbH, 01728 Bannewitz, Germany \\ ${ }^{3}$ Institute of Soil Sience and Site Ecology, Technische Universität Dresden, Dresden, Germany \\ Received: 19 Janary 2010 - Revised: 29 June 2010 - Accepted: 29 June 2010 - Published: 13 October 2010
}

\begin{abstract}
The hydromorphological analysis (HMA) is a method to quantify the potentials of mire revitalisation. In this study, the HMA is combined with the new peatland-tool of the water balance model AKWA-M ${ }^{\circledR}$. This peatland-tool includes as well depth functions of the hydraulic conductivity and drainable porosity for several mire-ecotope-types as specific equations for mire evapotranspiration. The calculations were applied in several peatlands and mires of the GermanCzech Ore Mountains (Erzgebirge/Krušné hory). The simulation results show that the chosen depth functions are valuable for the water balance calculation of mire ecotopes with a fully developed akrotelm like ombro- and mesotrophic peatlands. For degenerated peat soil or regenerating mires it is necessary to improve the model and the parameter calibration, especially the depth functions, with additional measured data in different peatlands.
\end{abstract}

\section{Introduction}

Mires are habitats, which developed from a special interaction of climate, water, relief, vegetation and peat substrate during thousands of years. Mires are increasingly recognised as valuable ecological systems. In Central Europe only a few remain undisturbed. Since decades they were drained for peat exploitation or forestal and agricultural use. Nowadays, big efforts are undertaken for their protection, conservation and revitalisation (restoration). The preservation and restoration of mires is as well interesting when debating the greenhouse gas influenced climate change, because of their function as a carbon sink.

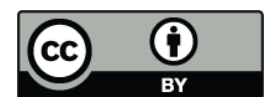

Correspondence to: F. Edom (frank.edom@t-online.de)
For several years our work group analyses mires in Saxony with the special attention on peat hydrology and structure. The aim of the research is to develop concepts for an effective revitalisation, bog protection and to define special habitats (e.g. according to EU-habitats-directive). The combination of knowledge, mire investigations and the HMA allow us to better understand the water supply and the internal water fluxes of mires or peatlands as well as to answer important questions: Which peatland-areas with which properties are regenerable as mires, and which rather not? Where and which actual measures improve the hydrologic regime? Which ecotopes or habitats could be developed in the future (ecotope-prognosis)? How does the mire behave with changed boundary conditions (drainage blocking, man made vegetation changes, climate change)?

\section{Hydromorphological analysis}

The hydromorphological theory of Ivanov (1975) was firstly used in Germany by Edom and Golubcov (1996). The authors transformed Ivanov's theory to predict the development of ecotopes in regenerating mire. In the following years this method was further developed. According to Edom et al. $(2007 \mathrm{a}, \mathrm{b}, \mathrm{c})$ this new procedures can be divided in two main parts: The hydromorphological analysis (HMA) and the prediction of possible stable ecotope zonations. In this article we will review results of the HMA. The principles of ecotop-prediction are publicated in Edom and Golubcov (1996), Edom (2001), Zinke and Edom (2006) and Edom et al. (2007c).

Hydromorphology describes a part of geomorphology concerning water formed elements of the landscape and their interactions. In mires the main forming processes are peataccumulation and peat-degradation, which depends on the

Published by Copernicus Publications on behalf of the European Geosciences Union. 
water regime, the peat-soil-structure and the plant communities. The mathematic expression of these processes is the causal-analytical hydromorphologic equation, a main part of "Ivanov's theory" (Ivanov, 1975). Equation (1) applies to a segment of the mire or the akrotelm:

$\frac{d y}{d l}(s)=\frac{q_{0} \cdot b_{0}+\int_{0}^{s} p_{1} \cdot b_{1} d l}{T_{z}(s) \cdot b_{\mathrm{s}}}=\frac{q_{\mathrm{s}} \cdot b_{\mathrm{s}}}{T_{z}(s) \cdot b_{\mathrm{s}}}$

where $d y / d l(s)$ is the slope of a surface element of the mire with the length $s$ downstream in the direction $l, q_{0} \cdot b_{0}$ is the long-term average inflow in the first segment with the inflow width $b_{0}, q_{\mathrm{s}} \cdot b_{\mathrm{s}}$ is the long-term average outflow in a segment with the outflow-width $b_{\mathrm{s}}$. The integral term contains the long-term average vertical water-balance $p_{1}$ with

$p_{1}=P-\mathrm{ET} \pm Q_{\mathrm{gw}}$

with $P$ the precipitation, ET the evapotranspiration and $Q_{\mathrm{gw}}$ the vertical groundwater-inflow or outflow (below the akrotelm or the peat-body). The long-term average (percolated) transmissivity of a peat column or the akrotelm $T_{z}(s)$ at the place $s$ is given by:

$T_{z}(s)=\int_{z_{m}}^{z_{u}} k_{\mathrm{f}}(z) d z$

with $z_{m}$ the long-term average water-table height and $z_{u}$ the lower limit of the peat body. Equation (3) includes the hydraulic conductivity $k_{\mathrm{f}}$ as an important hydraulic and sensitive parameter.

The HMA combines the knowledge about the mire (e.g. extension of peat body, peat depth, stratigraphy), the surface morphology, the vegetation and the water balance. It includes the mire and its catchment. We use now high resolution digital elevation models (DEM, resolution less than $5 \mathrm{~m}$ ) to derive the meso-relief and to generate a net of streamlines considering the mire surface slope. These streamlines subdivide the mire surface into stream sectors and the elevation contour lines split these sectors in segments. As a result the area, the shape and the slope of each segment are known. Edom and Golubcov (1996) rearranged Eq. (1) to the long-term average (potentially percolated) transmissivity for a single segment $i$ :

$T_{\mathrm{S}}(i)=\frac{q_{0} \cdot b_{0}}{b(i) \cdot d y / d l(i)}+\frac{\sum_{j=1}^{i} A_{j} \cdot\left(P-\mathrm{ET} \pm Q_{\mathrm{gw}}\right)_{j}}{b(i) \cdot d y / d l(i)}$

The sum term expresses the accumulation of the long-term average of vertical water-balance of all upstream segments draining into the segment $i$ and the vertical water-balance of considered segement $i$ itself, where $A$ is the area of each segment.
Using this equation many maps of potential transmissivities were calculated manually (Excel-worksheets) since 1993. In the last years the authors developed a GIS-tool to automate this procedure. The GIS-tool calculates for every single segment the accumulation of the water flow from upstream considering the silicate catchment and the peat-body. With the increase of accumulated flow in humid areas the transmissivity and the wetness usually rise. Note also the very important role of the slope $d y / d l$ within each grid. As an example Fig. 1 shows the calculated transmissivities for the mire "Mothhäuser Haide" in the middle Ore Mountains $\left(770 \mathrm{mHN}, 1.57 \mathrm{~km}^{2}\right)$. High transmissivity can be interpreted as a high potential for regeneration and successful implementation of restoration-mesurements.

As a simple approach to quantify the potential trophy of mire-regeneration Edom et al. (2007a,b,c) defined the minerotrophy-quotient $H(i)$ :

$$
H(i)=\frac{q_{0} \cdot b_{0} \sum_{j=1}^{i}\left[A_{j} \cdot Q_{\mathrm{gw}}(j)\right]}{q_{0} \cdot b_{0}+\sum_{j=1}^{i}\left[A_{j} \cdot P_{j}+Q_{\mathrm{gw}}(j)\right]}
$$

If $H(i) \geq 1$ the mire-segment and the origin of water is fully minerotrophic. With $H(i) \leq 0$ we have only ombrotrophic conditions. Mostly the values will be between 0 and 1 . Similar to the maps of transmissivity in the HAM maps of minerotrophy are calculated.

In the next step the drainage ditches are eliminated in the DEM to obtain the potential transmissivity respective to the pristine state. Hence, we calculate a theoretic state of the recent morphology without any ditches, which could be influenced by further peat-cutting or peat-shrinking near the ditches. It is also possible to modify areas to show the effects of planed or executed actions of revitalisation or changed boundary conditions (see Edom et al., 2007b, c).

\section{Water balance simulation}

The primary simulation method used monthly average climate data and widely unified equations and parameters from Russia (Edom, 2001) to calculate the long-term average water balance (Eq. 2) of peatlands. An example of such calculated water balances for two mires can be found in Edom et al. (2007a).

To include more vegetation types and to simulate the hydrological processes more in detail within each month we developed a specific peatland-tool for the water-balance-model AKWA-M ${ }^{\circledR}$ (Münch, 1994, 2008; Edom et al., 2008) in the last years. Some of the possibilities of this new peatland-tool are shown here.

The long-term water balance (Eq. 2) will be calculated for every segment in a temporal resolution of one day for a period of at least 10 years. The daily water balance can be 

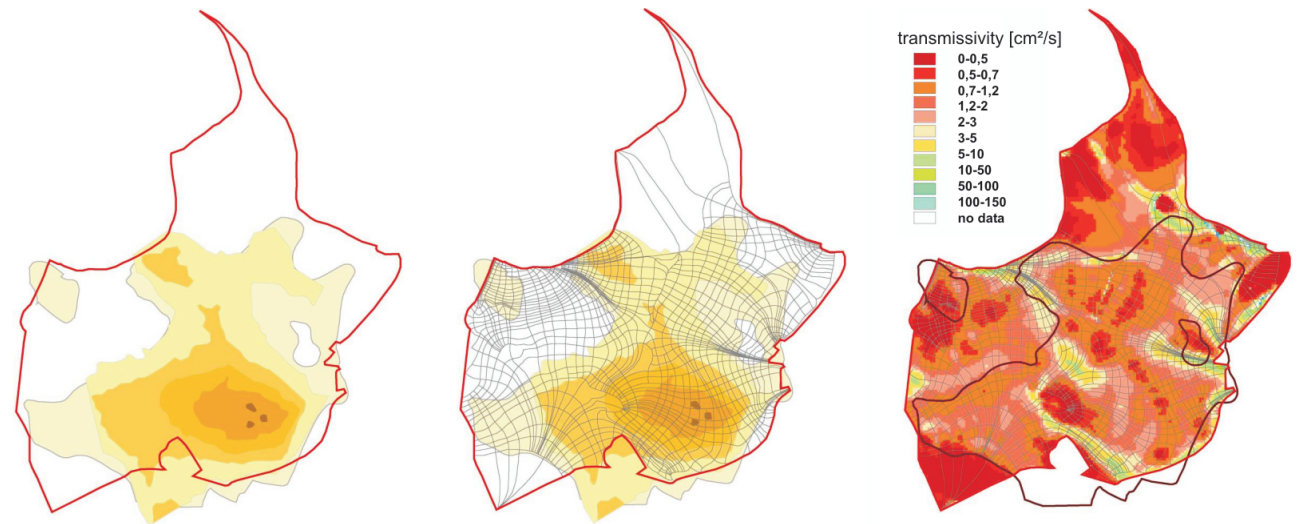

Fig. 1. Hydromorphological analysis for the mire "Mothhäuser Haide" (Ore Mountains, $770 \mathrm{mHN}$; left: catchment (red line) and peat depth (yellow: thin, orange: thick, red: up to $8 \mathrm{~m}$ ); middle: constructed streamlines and segments; right: map of potential transmissivity (red-dry, green-wet).

expressed in the form

$\Delta S=P_{k}-\mathrm{EI}-\mathrm{ET}_{\text {mire }}-\mathrm{ET}_{\text {tree }}-\mathrm{QH} \pm Q_{\mathrm{gw}}$

with $\Delta S$ as the daily change of storage. $P_{k}$ is the precipitation, corrected with additionals for systematic error of precipitation records and for fog depositions (high mountains and crests). EI is the interception of all vegetation, ET the transpiration, separate calculated for the mire and the trees (see Sect. 3.1). $\mathrm{QH}$ is a lateral water component and $Q_{\mathrm{gw}}$ the vertical groundwater exchange.

\subsection{Evapotranspiration}

The evapotranspiration of treeless or nearly treeless mires and of the soil-vegetation of wooded peatlands ET $_{\text {mire }}$ is calculated depending on groundwater table with the Romanovequation (1961):

$\mathrm{ET}_{\text {mire }}=\alpha \cdot \mathrm{RN}+\mathrm{Adv}$

with RN net radiation (special equations and parameters for mires see Bavina, 1979; Ivanova, 1990; Edom, 2001), Adv an advective term, which can be calculated according to Edom (2001). Following Romanov (1961, 1962), Bavina (1979), and Kaljužnyj et al. (1988) in humid, wet, cold and highly forested or wooded areas in the higher Ore mountains we mostly set $A d v=0$. Nethertheless the real influence of advection to mire-evaporation is not very well investigated (Edom, 2001; Frahm, 2007).

Romanov (1961, 1962), Bavina (1979), Kaljužnyj (1974) and Kaljužnyj et al. (1988) established from measurements the so called specific evapotranspiration $\alpha$ as a function of mire type, mire surface, season and groundwater table. Because $\alpha$ depends on groundwater-table height, the specific evapotranspiration can be described by depth-functions (Fig. 2).

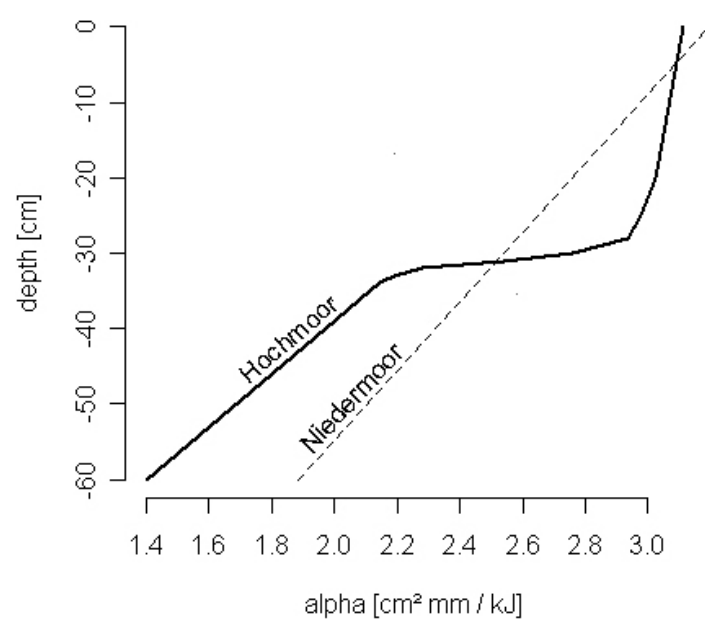

Fig. 2. Specific evapotranspiration $\alpha$ for $\operatorname{bog}=$ Hochmoor (Spagnum-lawn with low shrubs) and fen $=$ Niedermoor (brownmosssmall sedge-fen) by different groundwater tables in June, July, and August (combined by Romanov, 1961, 1962; Kaljužnyj et al., 1988; modified by Edom, 2001)

Analysing the depth-function for bogs (or the Sphagnumdominated akrotelm-structure) in Fig. 2, we suggest a sigmoide function (Edom et al., 2008):

$\alpha=(1-w) \cdot \alpha_{1}+w \cdot \alpha_{2}$

with

$w=\left(1+e^{\left(z_{\mathrm{b}}-z\right) / \tau}\right)^{-1}$

$z_{\mathrm{b}}$ is the boundary-depth in the akrotelm where the process regime changes (see Romanov, 1961, in Fig. $2 z_{\mathrm{b}}=30.5 \mathrm{~cm}$ ). $\tau=0.8 \mathrm{~cm}$ is the maximal slope of the sigmoide. For the month May we adapted from the Romanov-graphics (1961, 1962)

$\alpha_{1}=-0.01548 \cdot z+1.6905$ 


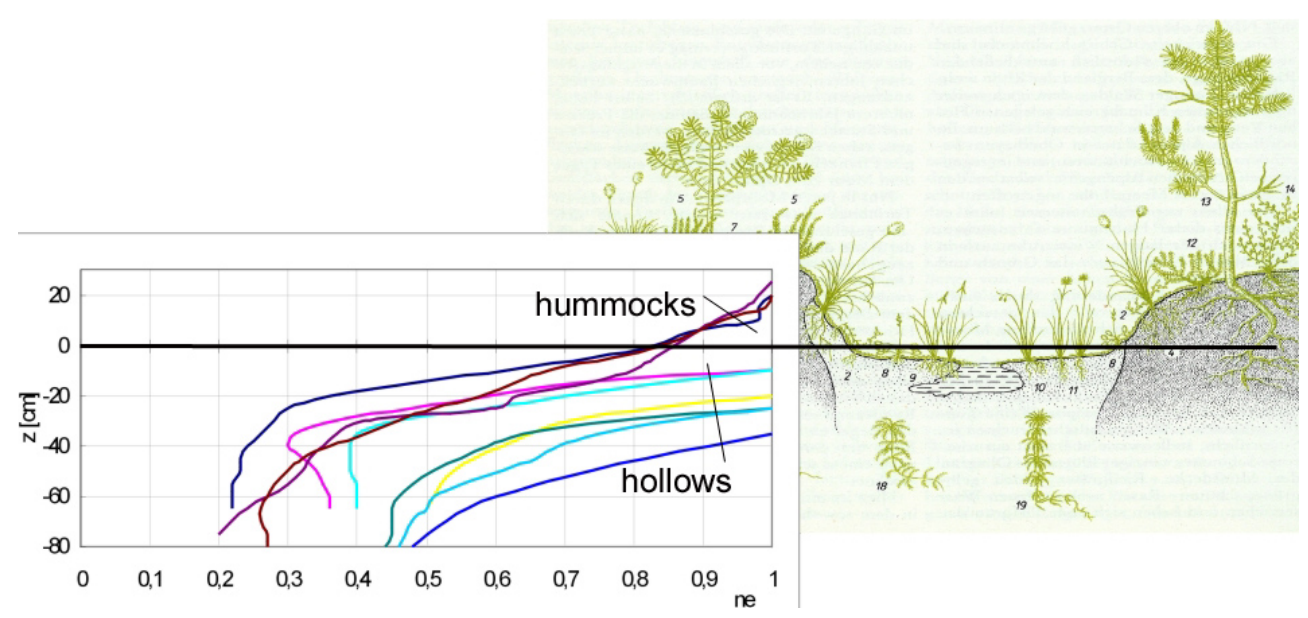

Fig. 3. Depth-functions of the drainable porosity $n_{\mathrm{e}}$ for hummocks and hollows, combined from Ivanov and Novikov (1976) and Slobodda (1987).

$\alpha_{2}=-0.002381 \cdot z+1.6905$

For the other months of the vegetation-period we have

$\alpha_{\text {month }}=c \cdot \alpha_{\text {Mai }}$

with $c_{\text {June, July, August }}=1.84$ and $c_{\text {September }}=0.5$.

The depth-function $\alpha_{\text {sedge }}$ for a brownmoss-small sedgefen (see Fig. 2) is linear (Romanov, 1961):

$\alpha_{\text {sedge }}=-0.0219 \cdot z+3.198$

The transpiration of peatland woods and forests is calculated in a two layer approach. In the upper layer the transpiration of trees $\mathrm{ET}_{\text {tree }}$ (if the mire or peatland is wooded) we calculate additionally with the Penman-Monteith equation. The transpiration of trees in peatlands is mostly calculated as potential (optimal) transpiration. But with high groundwater tables we reduce the transpiration of trees (conifers and birches) because of to high water levels similar to drought-stress (Ruseckas, 1997). The evapotranspiration of the mire-looking soil vegetation is simulated by the Eqs. (7)(13). The transforming of weather parameters radiation, wind and relative humidity is calculated with special functions using parameters of the stand-structure.

\subsection{Groundwater-table and exchange}

The groundwater-table in mires and peatlands is a key value to model the evapotranspiration and the vertical and horizontal groundwater-exchange $\left(Q_{\mathrm{gw}}\right.$ and $\left.\mathrm{QH}\right)$. However, the groundwater table is mostly the only measured value available to verify hydrological models in peatlands. Nevertheless, the groundwater-table fluctuations in the upper horizons can only be understood with additional information about the hydraulic structure of these horizons.

The hydraulic conductivity $k_{\mathrm{f}}$ varies in the upper layers of growing mires in a specific manner with the depth $z$. On the surface $\left(z=z_{\mathrm{o}}=0\right) k_{\mathrm{f}}$ is very large (living bog plants; $k_{\mathrm{f}}\left(z_{0}\right)=$ $\left.k_{0}\right)$. The conductivity decreases within the akrotelm zone because of the decomposition of the accumulated peat to the small values $k_{\mathrm{kat}}$ in the katotelm zone (peat below the minimal groundwater table). Romanov (1961), Ivanov (1975), Ivanov and Novikov (1976), Kaljužnyj et al. (1988), and Novikov (2009) found these coherences for different mireecotopes by conductivity measurements with the monolithmethod (Romanov, 1961; Ivanova, 1990; Novikov, 2009). Some of such depth-functions in graphics can be seen in Ivanov (1975) or Edom (2001). Wagner (2005) adjusted some of these in Russia publicated data to depth functions in the expression:

$k_{\mathrm{f}}(z)=k_{\mathrm{kat}}+\left(k_{\mathrm{o}}-k_{\mathrm{kat}}\right) \cdot e^{-z / m_{k}}$

with $k_{\text {kat }}$ and $k_{\mathrm{o}}$ are the hydraulic conductivity $k_{\mathrm{f}}$ on the top of the katolelm-zone and the surface. $m_{k}$ is an ecotopespecific parameter. These parameters vary for different ecotopes (peat vegetation types and mire-soils which are built of them). For the other important hydraulic parameter drainable porosity (storage-coefficient) $n_{\mathrm{e}}$ Wagner (2005) adapted similar depth functions by:

$n_{\mathrm{e}}(z)=n_{\text {kat }}+\left(n_{\mathrm{o}}-n_{\text {kat }}\right) e^{-\frac{z}{m_{n}}}$

Examples for such depth-functions with data from Ivanov and Novikov (1976) are shown in Fig. 3. This picture also shows that such depth-functions can vary in small (horizontal) distances.

The groundwater table results from the water column accumulated above the mire bottom by using the depth function for $n_{\mathrm{e}}$ and $k_{\mathrm{f}}$. The mire-hydrology of the Ivanov-school includes the hypothesis of "simultaneity of water-level fluctuations in all points of the mire massive" (Novikov, 2001, p. 97). Our experiences in peatlands of the Ore Mountains and of the Saxony lowlands support these observations. Because of this and since AKWA-M ${ }^{\circledR}$ has no linked segments 


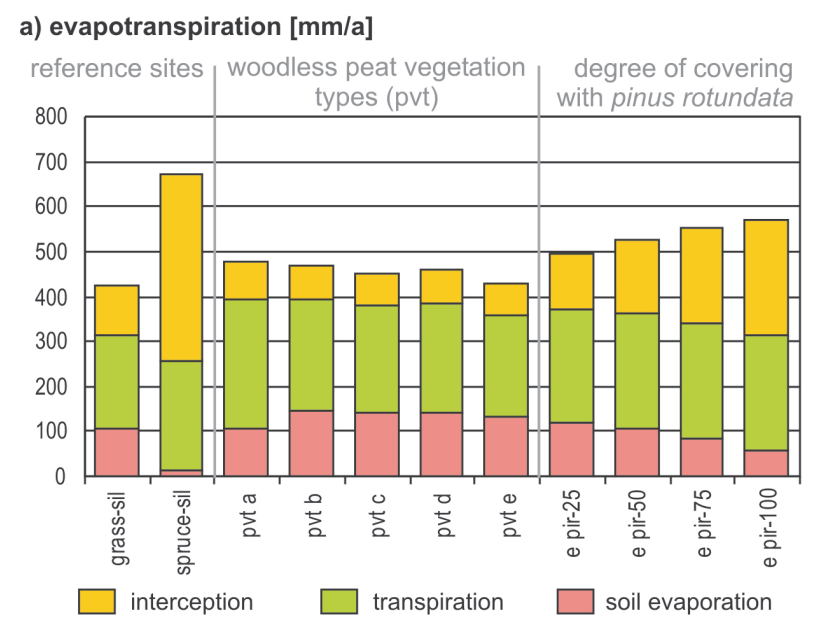

b) groundwater table [ $\mathrm{cm}$ below surface]

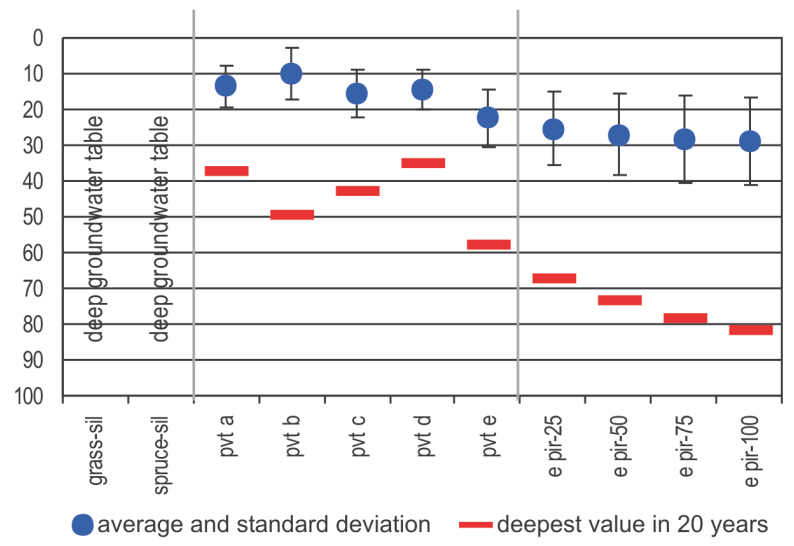

Fig. 4. Simulated long-term yearly average evapotranspiration and groundwater table for test sites with different peatland vegetation type according to Russian ecotopes ("mikrolandšafty"), (a) Micro-Carex-fen, (b) Sphagnum-low shrub-heath, (c) Sphagnum-low shrub-Eriophorum-lawn, (d) Sphagnum-Carex-low shrubEriophorum-lawn, (e) Bog-pine-Sphagnum low-shrub-heath) and density of canopy (wood covering) (25 light covered, 50 strong opened, 75 opened, 100 closed).

like the GIS-tool it was possible and necessary to insert a horizontal drainage component $\mathrm{QH}$ to compute the change of groundwater table

$\mathrm{QH}=I_{\mathrm{gw}} \cdot T(z) / b_{\mathrm{s}}$

where $I_{\mathrm{gw}}$ is the slope of groundwater table, depending on the surface slope and the parameters ditch depth and ditch density, which we get from the DEM, topographical maps and field studies. $b_{\mathrm{s}}$ is the segment width and $T(z)$ the transmissivity at the groundwater tabel $z$. In the peatland-tool the vertical groundwater exchange $Q_{\mathrm{gw}}$ in Eq. (6) is implemented as a small constant rate into the (mostly clay or loam) underground.

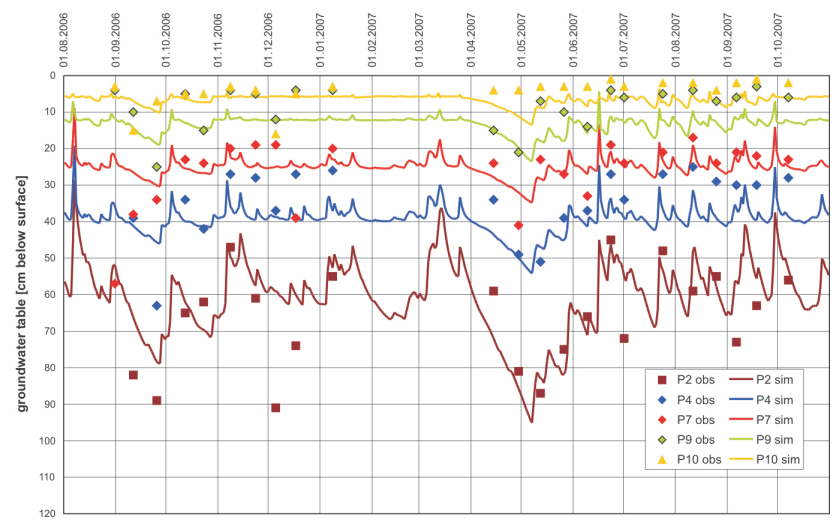

Fig. 5. Measured and calculatetd groundwater levels of observation wells within the peatland "Große Säure".

\section{Results of water-balance-simulation and discussion}

The peatland-tool of AKWA-M ${ }^{\circledR}$ was applied for different ombro- and mesotrophic peatlands in the Ore Mountains. Figure $4 a$ and $b$ show simulated long-term averages of evapotranspiration components and groundwater table for test sites. The reference sites are grassland and Norway spruce (Picea abies, matured forest) on silicatic soil and without groundwater influence as typical habitats in peatland catchments or groundwater recharge areas (left). In the middle of Fig. $4 \mathrm{a}$ and $\mathrm{b}$ are results for different woodless peat ecotope types and right for the increasing degree of the bog pine (Pinus rotundata). The Norway spruce has the highest evapotranspiration $(672 \mathrm{~mm} / \mathrm{a})$ due to the high interception. The tree coverage reduces the evaporation of the soil layer to a minimum due to a lower groundwater table, higher humidity, and less solar radiation input in the stand. The total evapotranspiration of woodless mires varies only as a result of different depth functions (Eqs. 14 and 15) from $478 \mathrm{~mm} / \mathrm{a}$ (micro-Carex-fen) to $430 \mathrm{~mm} / \mathrm{a}$ (Bog-pine-Sphagnum lowshrub-heath). Increasing tree density induces rising evapotranspiration up to $580 \mathrm{~mm} / \mathrm{a}$, but decreasing evapotranspiration of the soil cover. Figure $4 \mathrm{~b}$ shows the average and the total minimum of groundwater table. With the chosen parameters our woodless mire ecotopes have an average groundwater table between 10 and $22 \mathrm{~cm}$ below surface. With increasing tree density the groundwater table drops and the water table variation increases because of smaller $n_{\mathrm{e}}$ in higher depths.

Figure 5 presents the results for some groundwater observation wells in the peatland "Große Säure" (Ore Mountains, $920 \mathrm{mHN}$ ), which is part of the catchment of the creek Wilzsch and has been rewetted since 2007. In general the outflow for the whole catchment of the Wilzsch (catchment area at considered gauge $1.72 \mathrm{~km}^{2}, 30 \%$ mires) is simulated correctly and proved by the measured runoff-values of the 
Wilzsch. The mean value of observed discharge is $927 \mathrm{~mm} / \mathrm{a}$ within the years 2001-2007, the corresponding simulated discharge is $924 \mathrm{~mm} / \mathrm{a}$.

The simulated groundwater tables are similar to the observed, however with deeper groundwater levels the difference between measured and modelled values is sometimes large.

- The P2 and P4 sites are spruce stands with a high plant density and with soil vegetation, which is far from natural mires state. Soil profiles show that there is no natural akrotelm but high degenerated peat. Furthermore we found by peat coring at P2 a large macro-pore, which can lead to the decrease of the water table like calculated.

- Site P10 have the largest density of the mires typical species (Sphagnum dominates). In May 2007 the model calculates a decrease, which was not measured. However in all other observation plots this decrease was measured too. In this plot P10 a highly degenerated peat was found between 33 and $50 \mathrm{~cm}$ depth. This shows that this site was drained. At the present a new akrotelm is regenerating not being yet fully developed.

- P9 is a Sphagnum-Eriophorum lawn with small shrubs in a Pinus rotundata stand. The water tables were well modelled up to summer 2007. After that the observations show higher water tables. That shows that for this ecotope the parameters firstly where choosen well. But after the rewetting activities in summer and autumn 2007 the water level rised and the akrotelm was not in steady state with the new hydrologic regime. Furthermore during the soil survey degenerated horizons under the akrotelm were also found.

\section{Conclusions}

The method of hydromorphological analysis combines geomorphological features of mires and their catchments with the water balance. The AKWA-M ${ }^{\circledR}$-peatland-tool allows a better process-related water balance simulation with the inclusion of different ecotop-types and soil structures. The simulation results show that the chosen depth functions may be valuable for mire ecotopes with a fully developed akrotelm of ombro- and mesotrophic peatlands. Degenerated peat soil or regenerating mires dynamics must, however, be further analysed. Therefore it is necessary to improve the model and the parameter calibration, especially the depth functions, with additional observed data in different peatlands. Depth functions of $k_{\mathrm{f}}$ and $n_{\mathrm{e}}$ should also be measured in Central Europe by the monolith method. Especially forested or wooded peatlands and regenerating mires have a soil structure that differs from fully developed akrotelms; therefore the respective depth functions must also differ.
The variability of physical soil-parameters in space and time is very large (see also Zeitz, 1992). The vegetation cover alone does not provide enough information about the soil structure. Landscape-ecological investigations including soil, vegetation and hydrology (see Succow and Joosten, 2001) must be conducted also for wooded peatland and mires in the regeneration process. Furthermore long-term measurements of evapotranspiration of different peatland ecotopes, including the influence of the trees, should be organised.

Acknowledgements. We thank the Saxon Authority of Environmental Protection, Agriculture and Geology for supporting the hydromorphological analysis of the Mothhäuser Haide. This project also allows us to develop the peatland-tool. We say thanks to H. Neumeister (Geographic Institute of the Leipzig University) for providing the groundwater table data and to the Dam Authority of Saxony for the observed discharge in the Wilzsch-catchment.

Edited by: A. Wahren, F. Tavares Wahren, and K.-H. Feger

Reviewed by: N. Köplin and another anonymous referee

\section{References}

Bavina, L. G.: Isparenie i stok s neosusennych bolot v gody s razlicnoj uvlaznennost'ju, Trudy GGI, Vyp. 261, 61-73, 1979 (in in Russian).

Edom, F.: Moorlandschaften aus hydrologischer Sicht, Succow and Joosten, 185-228, 2001.

Edom, F. and Golubcov, A. A.: Zum Zusammenhang von Akrotelmeigenschaften und einer potentiell natürlichen Ökotopzonierung in Mittelgebirgsregenmooren (About the connection between akrotelm-parameters and a potential natural zoning of ecotopes in montane peat bogs), Verhandl. der Gesellsch. f. Ökol., Stuttgart, 26, 221-228, 1996.

Edom, F., Dittrich, I., Goldacker, S., and Keßler, K.: Die hydromorphologisch begründete Planung der Moorrevitalisierung im Erzgebirge, in: Praktischer Moorschutz im Naturpark Erzgebirge/Vogtland und Beispiele aus anderen Gebirgsregionen, Sächsische Landesstiftung Natur und Umwelt, Grillenburg, 1932, 2007a (in German).

Edom, F., Dittrich, I., Keßler, K., Goldacker, S., Wagner, M., and Golubcov, A. A.: Ökohydrologische Modellbildung auf der Grundlage von IVANOV's hydromorphologischer Theorie und Anwendungen im praktischen Naturschutz, Dresdener Schriften zur Hydrologie, 5, 90-98, 2007b (in German).

Edom, F., Golubcov, A. A., Dittrich, I., Zinke., P., and Solbrig, B.: Using IVANOV's hydromorphological theory in mire-ecology an introduction, in: Wetlands: Monitoring, Modelling and Management, edited by: Okruszko, T., Maltby, E., Szyatylowicz, J., Şwitek, D., and Kotowski, W., Taylor \& Francis Group, London, 239-247, 2007c.

Edom, F., Dittrich, I., Keßler, K., Münch, A., Peters, R., Theuerkauf, M., and Wendel, D.: Auswirkungen des Klimawandels auf wasserabhängige Ökosysteme, Teilprojekt Erzgebirgsmoore, Abschlußbericht des FuE-Vorhabens im Auftrag des Sächsischen Landesamtes für Umwelt und Geologie, Freiberg, Dr. Dittrich \& Partner Hydro-Consult GmbH Bannewitz, HYDROTELM Frank Edom Dresden and DUENE e.V. 
Greifswald, 91 S., 22 Anl. and 4 Anh., unpublished, 2008 (in German).

Frahm, E.: Bestimmung der realen Evapotranspiration für Weide (Salix spp.) und Schilf (Phragmites australis) in einem nordostdeutschen Flusstalmoor, Ph.D. thesis, University of Rostock, Institute of Environmental Engineering, Vol. 7, 202 pp., 2007 (in German).

Ivanov, K. E.: Vodoobmen v bolotnych landšaftach, Gidrometeoizdat, Leningrad, 1975 (in Russian).

Ivanov, K. E. and Novikov S. M.: Bolota Zapadnoj_Sibiri, ich stroenie i gidrologičeskij_režim, Gidrometeoizdat, Leningrad, 1976 (in Russian).

Ivanova, A. B. (Ed.): Nastavlenie gidrometeorologičeskim stancijam i postam, vyp. 8: Gidrometeorologičeskie nabljudenija na bolotach, Gidrometeoizdat, Leningrad, 1990 (in Russian).

Kaljužnyj, I. L.: Isparenie s bolotnych massivov raslicnych bolotnych provincij SSSR, Leningrad, Trudy GGI, Vyp. 222, 21-57, 1974 (in Russian).

Kaljužnyj, I. L., Pavlova, K. K., and Lavrov, S. A.: Gidrofičqeskie issledovani pri melioracii pereuvlažnennych zemel, Gidrometeoizdat, Leningrad, 1988 (in Russian).

Münch, A.: Wasserhaushaltsberechnungen für Mittelgebirgseinzugsgebiete unter Berücksichtigung einer sich ändernden Landnutzung, Diss., TU Dresden, Fak. f. Forst-, Geo- und Hydrowissenschaften, 1994 (in German).

Münch, A.: The water balance and rainfall runoff model AKWA$\mathrm{M}^{\circledR}$, User manual and documentation, Dr. Dittrich and Partner Hydro-Consult GmbH, Bannewitz, unpublished, 2008.

Novikov, S. M.: Bolota kak gidrologiceskij object. (Mires like a hydrological object), in: Torfjannye bolota Rossii, k analizu otraslevoj informacii, edited by: Sirin, A. A. and Minajeva, T. J., Wetlands International, GEOS, Moskva, 2001 (in Russian).
Novikov, S. M. (Ed.): Gidrologija zaboločennych territorij zony mnogoletnej merzloty Zapadnoj Sibiri, VVM St. Peterburg, 535 pp., 2009 (in Russian).

Romanov, V. V.: Gidrofizika bolot, Gidrometeoizdat, Leningrad, 1961 (in Russian).

Romanov, V. V.: Isparenie s bolot Evropejskoj territorii SSSR (Verdunstung der Moore vom Europäischen Teil der UdSSR), Gidrometeoizdat, Leningrad, 228 pp., 1962.

Ruseckas, J.: Application of Modelling Methods to Study Water Budgets in Forested Peatlands. Chapter 16, in: Northern Forested Wetlands,

Trettin, C. C., Jurgensen, M. F., Grigal, D. F., Gale, M. R., Jeglum, J. R., Lewis Publishers, 231-237, 1997.

Slobodda, S.: Pflanzengemeinschaften und ihre Umwelt, 2nd edn., Urania Leipzig, Jena, Berlin, 1987.

Succow, M. and Joosten, H.: Landschaftsökologische Moorkunde, Zweite, völlig neu bearb, Auflage. E. Schweitzerbartsche Verlagsbuchhandlung, Stuttgart, 2001 (in German).

Wagner, M.: Ableitung und Diskussion einer hydromorphologischen Impulsantwortfunktion zur Beschreibung des Abflußverhaltens naturnaher Mittelgebirgsmoore, Diploma-thesis, TU Dresden, unpublished, 2005 (in German).

Zeitz, J.: Bodenphysikalische Eigenschaften von SubstratHorizont-Gruppen in landwirtschaftlich genutzten Niedermooren, Zeitschrift für Kulturtechnik und Landentwicklung, 33, 301-307, 1992.

Zinke, P. and Edom, F.: Hydraulische und hydrologische Erklärung von Ökotopstrukturen am Regenmoor Kriegswiese im mittleren Erzgebirge, Archiv Naturschutz and Landschaftsforschung, 45(2), 43-60, 2006 (in German). 